\title{
Disparate access to nutritional food; place, race and equity in the United States
}

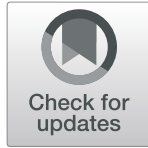

Garett Sansom ${ }^{*}$ (D) and Bryce Hannibal ${ }^{2}$

\begin{abstract}
Background: Prior research has demonstrated minority communities have fewer options to access healthy foods when compared to their majority counterparts. While much focus has been placed upon community-level resources, little research has been placed on the efforts that minority groups need to undergo to reach wellstocked stores to purchase healthy food options.

Methods: As part of the Water, Energy, Food Nexus Research Group at Texas A\&M University, a nationally representative survey $(n=1612)$ was conducted to acquire self-reported distance, time, and motives that certain populations must travel to purchase food for themselves and their families.
\end{abstract}

Results: Findings suggest that minority populations consider saving money, driving less, having a better selection of foods, and have the ability to buy organic foods as an important factor when choosing where to buy foods. Further, minority populations across the nation need to drive a significantly greater $(p<0.05)$ amount of time to reach their destinations than white populations.

Conclusion: This underscores the importance, and scope of the issues, of promoting and implementing more equitably distributed opportunities to purchase healthy food options throughout the United States.

Keywords: Food desert, Nutrition, Minority, Obesity, Equity

\section{Background}

The unequal access to affordable high-quality food within the United States has been highlighted in recent years. In 2013, there were an estimated 17.5 million households that were food insecure with a disproportionate burden placed upon African American and Hispanic homes [1]. Further, disparate rates of obesity and obesity-related illness among minority majority communities, in comparison to majority neighborhoods, have been conclusively shown $[2,3]$. The primary explanation for these differences is the existence of "food deserts" within marginalized communities throughout the United States [4]. Food deserts, to be understood as a geographic region in which it is difficult to purchase

\footnotetext{
* Correspondence: sansom@tamhsc.edu; sansom@tamhsc.edu

${ }^{1}$ Department of Environmental and Occupational Health, Texas A\&M School of Public Health, 1266 TAMU, College Station, TX 77843, USA

Full list of author information is available at the end of the article
}

affordable high-quality food, has been empirically shown to exist primarily in minority neighborhoods $[5,6]$. While much research on access to supermarkets have involved utilizing directories and census data [7, 8], food store assessments [7, 9], and Geographic Information Systems (GIS) [10, 11], little work has been conducted using a nationally representative questionnaire. The importance of creating an environment that is conducive to living a healthy lifestyle cannot be overstated and access to quality food is a vital facet in that calculation.

The World Health Organization (WHO) has declared that obesity is one of the most serious public health issues in the twenty-first century. While access to highquality food is scarce in African American communities, calorie dense fast-food restaurants are in abundance. A food density study showed that neighborhoods with an $80 \%$ or greater proportion of African American residents had an average of 2.4 restaurants $/$ mile $^{2}$ compared to 1.5

(c) The Author(s). 2021 Open Access This article is licensed under a Creative Commons Attribution 4.0 International License, which permits use, sharing, adaptation, distribution and reproduction in any medium or format, as long as you give appropriate credit to the original author(s) and the source, provide a link to the Creative Commons licence, and indicate if changes were made. The images or other third party material in this article are included in the article's Creative Commons licence, unless indicated otherwise in a credit line to the material. If material is not included in the article's Creative Commons licence and your intended use is not permitted by statutory regulation or exceeds the permitted use, you will need to obtain permission directly from the copyright holder. To view a copy of this licence, visit http://creativecommons.org/licenses/by/4.0/ The Creative Commons Public Domain Dedication waiver (http://creativecommons.org/publicdomain/zero/1.0/) applies to the data made available in this article, unless otherwise stated in a credit line to the data. 
restaurants/mile ${ }^{2}$ in neighborhoods with only $20 \%$ African American residents [12]. This reality has led to Hispanic and Non-Hispanic Black communities shouldering the highest levels of obesity in the United States [13].

Another barrier to equitable food access is costs associated with purchasing groceries. A Seattle-based obesity study [14] conducted a survey $(n=1682)$ on selfreported obesity rates and socioeconomic status variables as well as stratified supermarkets by price of goods and distance to participants. It was discovered that an inverse relationship existed between price and obesity levels, indicating that access to affordable nutritional foods is difficult for many individuals.

Rural communities have also been shown to provide fewer locations to access healthy foods for local residents, however, rural residents that are higher income and predominantly white often have the means to travel farther distances to access more nutritional options [2]. Little research has addressed, at a national level, (1) the time spent traveling to supermarkets and local grocery stores by race (2) the reasoning for traveling to specific locations, be it financial or quality of product, and (3) if rural minority populations in rural locations shoulder an unfair burden in accessing nutritional food compared to their rural white counterparts. This research seeks to close the gap on these research questions.

\section{Methods}

\section{Survey}

As part of the Water, Energy, Food (WEF) Nexus Research Group at Texas A\&M University, a panuniversity multi-year research endeavor, a nationally representative survey was administered in August 2015. The survey aimed to determine a variety of environmental and WEF issues including access to supermarkets and grocery stores, time spent traveling to these locations, and reasons for traveling to specific locations over others. The data was collected by GfK Custom Research who administered this nationally representative public opinion survey to adults who were 18 years or older. All participants provided written consent.

Survey data collected through KnowledgePanel ${ }^{\circ}$ perfectly matches the most current benchmarks of the Current Population Survey along several important demographic dimensions to be representative of the larger U.S. population, and post-stratification survey weights were included in the analysis to ensure U.S. population representation, thus providing a more generalizable results based upon demographic and socioeconomic variables. When potential respondents did not have adequate access to internet or a computer, GfK provided internet access and a laptop so that the individual could complete the survey. Detailed description of this survey administration and instrument items is available in previous research $[15,16]$. The median survey completion time was $24 \mathrm{~min}$ and upon completion the respondents were entered into raffles for cash rewards and other prizes.

\section{Study instruments}

The dependent variables of interest here examine different aspects of choice of where the individual purchases foods as well as the amount of time it takes for the respondent to travel to where they purchase foods. Each dependent variable measures a distinct component of access to fresh foods or factors that may complicate access to fresh foods. To illustrate, individuals who live in large cities and use public transportation may have difficulty transporting groceries home and instead choose to shop at gas stations, or other convenience stores. The difficulty accessing fresh fruits and vegetables may compromise their health over a number of years.

We examine 5 dependent variables that address foodrelated issues. Specifically, we ask respondents "When you buy food, how important is each of the following reasons for choosing where you purchase your food?" The survey items are: save money, drive less, better selection of food, and ability to buy organic foods. Each item is treated as its own dependent variable. The answers range from 1 to 5 where $1=$ not important, $2=$ somewhat important, $3=$ important, $4=$ very important, and $5=$ extremely important. We also ask respondents "how long (in minutes) does it take you to travel to where you buy most of your food?" This is an openended question and we use the respondents written-in answer as another dependent variable.

The primary predictor variable of interest is racial minority status. This is a binary variable where white nonHispanic $=0$ and racial minority $=1$. The binary variable is derived from the race categories noted in Table 1. In addition to minority status, we also control for several other socio-demographic characteristics that could influence food purchase choices. Household income is on an 11 -point scale where $1=$ less than $\$ 10,000$ per year and 11 = greater than $\$ 125,000$ per year. Education is on a 5point scale where $1=$ less than high school and $5=$ professional degree. Conservative political ideology is a sliding scale that ranges from 1 to 7 where $1=$ extremely liberal and $7=$ extremely conservative. Age is the respondents reported age in years. Sex_Female is $1=$ female and $0=$ otherwise. Employment status is a binary variable where $1=$ currently employed and $0=$ otherwise. Finally, metropolitan statistical area (MSA) status captures whether the respondent live in a predominantly rural or metropolitan area, where $1=$ metropolitan and $0=$ otherwise.

Bivariate regression as well as multivariate were calculated and reported. We estimate an ordered logistic 
Table 1 Descriptive Statistics: Predictor Variables

\begin{tabular}{ll}
\hline Characteristics & N (\%) \\
\hline Sex & \\
Male & $798(49.5)$ \\
Female & $814(50.5)$ \\
Income & \\
$<\$ 20,000$ & $207(12.85)$ \\
$\$ 20,000-\$ 40,000$ & $345(21.41)$ \\
$\$ 40,000-75,000$ & $406(25.19)$ \\
$>\$ 75,000$ & $654(40.57)$ \\
Race & \\
Non-Hispanic White & $1182(73.33)$ \\
LatinX & $164(10.17)$ \\
African American & $153(9.49)$ \\
Other & $52(3.23)$ \\
Age in Years & \\
Mean (SD) & $49.86(17.30)$ \\
Age in Groups & \\
$<29$ & $272(17)$ \\
$30-44$ & $364(23)$ \\
$45-59$ & $452(28)$ \\
$60+$ & $524(32)$ \\
\hline
\end{tabular}

regression and an ordinary least squares regression, both with robust standard errors, to determine the relationship between sociodemographic characteristics and food choice characteristics. We use an ordered logistic regression because four of the dependent variables are bound and ranked from low to high. For the Minutes to Store variable we estimate and ordinary least square regression. Because of the skewed distribution of the Minutes to Store variable, we use a natural log transformation in the statistical regression.

\section{Results}

A nationally representative sample was attempted as can be seen in Table 1 . The response rate of $61.0 \%$ yielded a sample size of 1612 or 1612 completed surveys. There was rough parity between men and women and broad representation of differing incomes. While there was slight over representation of non-Hispanic white individuals (73\%), minority status participants had sizable representation (26\%), and a wide range of ages were present with a mean age of 49.86 . Of the respondent's $18.67 \%$ resided in a rural location $(n=301)$ and $81.33 \%(n=1311)$ resided in a metropolitan region. This is aligned with national data collected by the US Census that also reveals $80 \%$ in urban and $20 \%$ in rural locations across the country [17].
Descriptive statistics for responses to the main reasons to travel further to find and acquire food is presented in Table 2. These 5 dependent variables represent the main drivers of food choice as revealed through this survey. Overall individuals' priority in choosing the location to shop was to save money, followed by better selection of food, proximity to store, travel time, and finally ability to buy organic foods. This accounts for all individuals regardless of race, income, or age.

Results from the statistical analyses are presented in Table 3. As stated above, we are primarily interested in the relationships between the food security characteristics and minority status. As such we present results from a bivariate regression as well as multivariate, which includes the variables listed previously. We also interpret significant coefficients as odds ratios with robust standard errors, where appropriate.

Across all bivariate models, where minority status is treated as the only covariate, we find that there is a positive and significant relationship. This suggests that minorities consider saving money, driving less, having a better selection of foods, and have the ability to buy organic foods as an important factor when choosing where to buy foods. Specifically, we find that minorities are approximately $30 \%$ more likely to think that saving money is important, $25.2 \%$ more likely to consider driving less as important, about $34 \%$ more likely to think selection of food is important, and nearly twice as likely (1.918) when considering the ability to buy organic food as important when compared to non-minorities in deciding where to purchase foods. Similarly, we find that minorities travel farther (in minutes) than non-minorities to the specific location where they buy their foods. This relationship is also statistically significant.

There was also a divide between urban and rural populations. While African American populations travel the furthers distance to acquire food, Hispanic groups travel the least distance.

\section{Discussion}

This research suggests a desire within minority communities to have greater access to healthy food options in closer proximity to their homes. Further, minority populations are significantly ( $p$-value $<0.001)$ more likely to have to drive further to arrive at these desired grocery

Table 2 Descriptive Statistics: Dependent Variables

\begin{tabular}{lllll}
\hline & Mean & Std. Dev. & Min & Max \\
\hline Save Money & 3.80 & 1.06 & 1 & 5 \\
Drive Less & 3.02 & 1.17 & 1 & 5 \\
Better Selection of Food & 3.64 & 1.02 & 1 & 5 \\
Ability to buy organic foods & 2.18 & 1.27 & 1 & 5 \\
Travel time in minutes (NL) & 2.22 & 0.71 & 0 & 4.79 \\
\hline
\end{tabular}


Table 3 Bivariate and Multivariate Results Predicting Access to Foods

\begin{tabular}{|c|c|c|c|c|c|c|c|c|c|c|}
\hline \multirow[b]{2}{*}{ Minority Status } & \multicolumn{2}{|c|}{ Save Money } & \multicolumn{2}{|c|}{ Drive Less } & \multicolumn{2}{|c|}{ Better Selection } & \multicolumn{2}{|c|}{ Buy Organic Foods } & \multicolumn{2}{|c|}{ Minutes to Store } \\
\hline & $1.306^{* *}$ & 1.209 & $1.252^{*}$ & 1.132 & $1.343^{* *}$ & $1.353^{* *}$ & $1.918^{* * *}$ & $1.954^{* * *}$ & $0.139^{* * *}$ & $0.183^{* * *}$ \\
\hline & $(0.144)$ & $(0.144)$ & $(0.132)$ & $(0.130)$ & $(0.149)$ & $(0.161)$ & $(0.201)$ & $(0.227)$ & $(0.040)$ & $(0.042)$ \\
\hline \multirow[t]{2}{*}{ Household Income } & & $0.925^{* * *}$ & & $0.951^{* *}$ & & 1.022 & & 1.006 & & 0.001 \\
\hline & & $(0.016)$ & & $(0.016)$ & & $(0.018)$ & & $(0.017)$ & & $(0.006)$ \\
\hline \multirow[t]{2}{*}{ Education } & & 0.925 & & 0.961 & & 0.986 & & $1.166^{* * *}$ & & $-0.039^{* *}$ \\
\hline & & $(0.043)$ & & $(0.041)$ & & $(0.043)$ & & $(0.050)$ & & $(0.016)$ \\
\hline \multirow[t]{2}{*}{ Age } & & $0.992^{* *}$ & & 1.001 & & 1.004 & & $0.988^{* * *}$ & & 0.001 \\
\hline & & $(0.003)$ & & $(0.003)$ & & $(0.003)$ & & $(0.003)$ & & $(0.001)$ \\
\hline \multirow[t]{2}{*}{ Female } & & 1.131 & & $1.403^{* * *}$ & & $1.242^{*}$ & & $1.233^{*}$ & & 0.061 \\
\hline & & $(0.108)$ & & $(0.134)$ & & $(0.117)$ & & $(0.120)$ & & $(0.035)$ \\
\hline \multirow[t]{2}{*}{ Employment Status } & & 1.010 & & 1.043 & & 0.923 & & $0.794^{*}$ & & $-0.137^{* * *}$ \\
\hline & & $(0.109)$ & & $(0.111)$ & & $(0.102)$ & & $(0.086)$ & & $(0.039)$ \\
\hline \multirow[t]{2}{*}{ MSA Status } & & $1.582^{* * *}$ & & $1.446^{* * *}$ & & 1.245 & & 0.926 & & $-0.298^{* * *}$ \\
\hline & & $(0.200)$ & & $(0.162)$ & & $(0.151)$ & & (0.109) & & $(0.046)$ \\
\hline \multirow[t]{2}{*}{ Constant cut1 } & $0.022^{*}$ & $0.015^{*}$ & $0.131^{*}$ & $0.092^{*}$ & $0.036^{*}$ & $0.044^{*}$ & $0.860^{*}$ & $0.463^{*}$ & & \\
\hline & $(0.004)$ & $(0.005)$ & $(0.011)$ & $(0.026)$ & $(0.005)$ & $(0.014)$ & $(0.049)$ & $(0.123)$ & & \\
\hline \multirow[t]{2}{*}{ Constant cut2 } & $0.134^{*}$ & $0.100^{*}$ & $0.507^{*}$ & $0.365^{*}$ & $0.139 *$ & $0.181^{*}$ & $2.086^{*}$ & 1.146 & & \\
\hline & $(0.011)$ & $(0.030)$ & $(0.030)$ & $(0.100)$ & $(0.011)$ & $(0.055)$ & $(0.126)$ & $(0.303)$ & & \\
\hline \multirow[t]{2}{*}{ Constant cut3 } & $0.698^{*}$ & $0.543^{*}$ & $2.238^{*}$ & 1.668 & $0.831^{*}$ & 1.098 & $6.187^{*}$ & $3.432^{*}$ & & \\
\hline & $(0.040)$ & $(0.162)$ & $(0.136)$ & $(0.457)$ & $(0.047)$ & $(0.327)$ & $(0.470)$ & $(0.911)$ & & \\
\hline \multirow[t]{2}{*}{ Constant cut4 } & $2.180^{*}$ & 1.740 & $7.094^{*}$ & $5.301^{*}$ & $3.847^{*}$ & $5.118^{*}$ & $15.245^{*}$ & $8.421^{*}$ & & \\
\hline & $(0.129)$ & $(0.518)$ & $(0.556)$ & (1.503) & $(0.252)$ & $(1.541)$ & $(1.545)$ & $(2.353)$ & & \\
\hline \multirow[t]{2}{*}{ Constant } & & & & & & & & & $2.185^{*}$ & $2.590^{*}$ \\
\hline & & & & & & & & & $(0.020)$ & $(0.102)$ \\
\hline Wald $\mathrm{Chi}^{2}$ & $5.92^{* * *}$ & $61.49 * *$ & $4.54^{* * *}$ & $52.34^{* * *}$ & $7.07^{* * *}$ & $27.62^{* * *}$ & $28.63^{* * *}$ & $86.87^{* * *}$ & & \\
\hline R-squared & & & & & & & & & 0.008 & 0.061 \\
\hline Pseudo $R^{2}$ & 0.001 & 0.018 & 0.001 & 0.011 & 0.002 & 0.007 & 0.009 & & & \\
\hline$F$ & & & & & & & & & $12.05^{* * *}$ & $12.28^{* * *}$ \\
\hline
\end{tabular}

stores. However, Hispanic groups did not see these same results. These findings provide insight on the importance of certain characteristics that remain prevalent when deciding where people in minority groups purchase food. Other research has found a similar result in rural areas in Texas in which Hispanic groups had better access to food sources than other minority populations [18] contrary to urban regions. One possible explanation for this is the rise of ethnic food marts and farmers markets catering to a rising population of Hispanic populations in the United States and points to a possible road map to improve food access to other groups and within urban areas.

This study has several important limitations. This utilized a cross-sectional study design in which characteristics of the predictor and dependent variables were collected simultaneously and does not allow for analysis over periods of time. As a result, we cannot, and do not imply any causal relationships here. Additional analyses that focus on decision-making processes regarding food purchase patterns and changes in one's economic environment would illustrate important nuances to this argument. Further, data was self-reported and subjected to recall bias, previous research on dietary intake $[19,20]$, as well as estimates on time travelled [21] has found that both underestimate the time and amount consumed, this suggests that our results may be pulled toward the null hypothesis. As is typical with survey data, there is a possibility that qualitative difference in individuals' lives may influence decisions. Additionally, some cultural differences are omitted in survey analysis. Finally, while many participants provided data, the response rate was low (61\%). The results did benefit from a nationally representative sample and many important potentially 
confounding variables were collected. Furthermore, the results are consistent across multiple models and provide further evidence that food availability is unequal across racial category.

Diet and nutrition play a critical role in living a healthy life and are drivers of chronic health conditions and obesity levels [22]. It is becoming a public health crisis that is impacting the most vulnerable communities among us. While these results point towards an unequal access to healthy foods, implementation of food desert interventions need to operate with care. Research Sullivan (2014) found that when culturally appropriate grocery stores are not implemented in gentrified communities, minority populations fail to shop within them [23]. The findings from this research build upon previous work ad indicate at least one facet of this problem and may provide opportunities for future interventions and target polices.

\section{Conclusion}

In this nationally representative sample, we found that minority populations travel further to reach grocery stores that served their needs and were more likely to consider organic food selection and price to be important factor when selecting a grocery store when compared to non-Hispanic white populations. This research furthers previous studies that have confirmed both an unequal access to affordable, nutritious food options [24], but also highlights individuals desire for better selections for them and their families within minority groups. The importance in creating programs and policies that address food insecurity is underscored by the reality that minority populations shoulder the largest burden of negative health conditions associated with a poor diet, linking their neighborhood characteristics to health implications.

\section{Abbreviations}

GIS: Geographic Information Systems; WHO: World Health Organization; WEF: Water, Energy, Food; MSA: Metropolitan Statistical Area

\section{Supplementary Information}

The online version contains supplementary material available at https://doi. org/10.1186/s40795-021-00434-2.

\section{Additional file 1.}

\section{Acknowledgements}

The authors wish to thank the assistance from the Texas A\&M University Water, Energy, Food (WEF) Nexus Research Group.

\section{Authors' contributions}

The authors' responsibilities are as follows: GS and BH concieved and researched the topic; $\mathrm{BH}$ conducted data analysis; GS and $\mathrm{BH}$ wrote the manuscript. All authors have read and approved the final manuscript.

\section{Funding}

Funded through internal support at Texas A\&M University. The funding source played no roles in the design of the study, collection, analysis, or interpretation of data or in writing the manuscript.

Availability of data and materials

Upon reasonable request data may be made available, please contact sansom@tamhsc.edu

\section{Declarations}

Ethics approval and consent to participate

Written consent was received from all participants and all research was approved through the Texas A\&M University Institutional Review Board.

Consent for publication

Not applicable.

\section{Competing interests}

The authors declare that they have no competing interests.

\section{Author details}

${ }^{1}$ Department of Environmental and Occupational Health, Texas A\&M School of Public Health, 1266 TAMU, College Station, TX 77843, USA. ${ }^{2}$ Bush School of Government and Public Service, Texas A\&M University, 4220 TAMU,

College Station, TX 77843, USA.

Received: 29 May 2020 Accepted: 4 May 2021

Published online: 29 June 2021

References

1. Coleman-Jensen A, Gregory C, Singh A. Household food security in the United States in 2013. USDA-ERS Econ Res Rep. 2014;11(173). https://dx.doi. org/10.2139/ssrn.2504067.

2. Walker RE, Keane CR, Burke JG. Disparities and access to healthy food in the United States: a review of food deserts literature. Health Place. 2010;16(5): 876-84. https://doi.org/10.1016/j.healthplace.2010.04.013.

3. Manson JE, Skerrett PJ, Greenland P, Vanltallie TB. The escalating pandemics of obesity and sedentary lifestyle: a call to action for clinicians. Arch Intern Med. 2004;164(3):249-58. https://doi.org/10.1001/archinte.164.3.249.

4. Hendrickson D, Smith C, Eikenberry N. Fruit and vegetable access in four low-income food deserts communities in Minnesota. Agric Hum Values. 2006;23(3):371-83. https://doi.org/10.1007/s10460-006-9002-8.

5. Block D, Kouba J. A comparison of the availability and affordability of a market basket in two communities in the Chicago area. Public Health Nutr. 2006;9(7):837-45. https://doi.org/10.1017/PHN2005924.

6. Moore LV, Diez-Roux AV. Associations of neighborhood characteristics with the location and type of food stores. Am J Public Health. 2006:96(2):325-31. https://doi.org/10.2105/AJPH.2004.058040.

7. Alwitt LF, Donley TD. Retail Stores in Poor Urban Neighborhoods. J Consum Aff. 1997;31(1):139-64. https://doi.org/10.1111/j.1745-6606.1997.tb00830.x.

8. Powell LM, Slater S, Mirtcheva D, Bao Y, Chaloupka FJ. Food store availability and neighborhood characteristics in the United States. Prev Med. 2007;44(3): 189-95. https://doi.org/10.1016/j.ypmed.2006.08.008.

9. Zenk SN, Schulz AJ, Israel BA, James SA, Bao SM, Wilson ML. Fruit and vegetable access differs by community racial composition and socioeconomic position in Detroit, Michigan. Ethn Dis. 2006;16(1):275-80.

10. Giang T, Karpyn A, Laurison HB, Hillier A, Perry RD. Closing the grocery gap in underserved communities: the creation of the Pennsylvania fresh food financing initiative. J Public Health Manag Pract. 2008;14(3):272-9. https:// doi.org/10.1097/01.PHH.0000316486.57512.bf.

11. Raja S, Ma C, Yadav P. Beyond food deserts: measuring and mapping racial disparities in neighborhood food environments. J Plan Educ Res. 2008;27(4): 469-82. https://doi.org/10.1177/0739456X08317461.

12. Block JP, Scribner RA, DeSalvo KB. Fast food, race/ethnicity, and income. Am J Prev Med. 2004;27(3):211-7. https://doi.org/10.1016/j.amepre.2004.06.007.

13. Hales CM, Carroll MD, Fryar CD, Ogden CL. Prevalence of obesity among adults and youth: United States, 2015-2016; 2017.

14. Drewnowski A, Aggarwal A, Hurvitz PM, Monsivais P, Moudon AV. Obesity and supermarket access: proximity or price? Am J Public Health. 2012;102(8): e74-80. https://doi.org/10.2105/AJPH.2012.300660. 
15. Hannibal B, Vedlitz A. Throwing it out: introducing a nexus perspective in examining citizen perceptions of organizational food waste in the US. Environ Sci Pol. 2018;88:63-71. https://doi.org/10.1016/j.envsci.2018.06.012.

16. Hannibal B, Sansom L, Portney EK. The effect of local water scarcity and drought on water conservation behaviors. Environ Soc. 2019;5(3):294-307.

17. Ratcliffe M, Burd C, Holder K, Fields A. Defining Rural at the U.S. Census Bureau. Washington, DC: ACSGEO-1, U.S. Census Bureau; 2016.

18. Sharkey JR, Horel S. Neighborhood socioeconomic deprivation and minority composition are associated with better potential spatial access to the ground-truthed food environment in a large rural area. J Nutr. 2008;138(3): 620-7. https://doi.org/10.1093/jn/138.3.620.

19. Bandini LG, Must A, Cyr H, Anderson SE, Spadano JL, Dietz WH. Longitudinal changes in the accuracy of reported energy intake in girls 10-15 y of age. Am J Clin Nutr. 2003;78(3):480-4. https://doi.org/10.1093/ajcn/78.3.480.

20. Bandini LG, Schoeller DA, Cyr HN, Dietz WH. Validity of reported energy intake in obese and nonobese adolescents. Am J Clin Nutr. 1990;52(3):4215. https://doi.org/10.1093/ajcn/52.3.421.

21. Petrunoff NA, Xu H, Rissel C, Wen LM, van der Ploeg HP. Measuring workplace travel behaviour: validity and reliability of survey questions. J Environ Public Health. 2013;2013:423035-6. https://doi.org/10.1155/2013/423 035.

22. Nishida C, Uauy R, Kumanyika S, Shetty P. The joint WHO/FAO expert consultation on diet, nutrition and the prevention of chronic diseases: process, product and policy implications. Public Health Nutr. 2004;7(1a):24550. https://doi.org/10.1079/PHN2003592.

23. Sullivan DM. From food desert to food mirage: Race, social class, and food shopping in a gentrifying neighborhood. Advances in Applied Sociology. 2014.

24. Freedman DA. Local food environments: they're all stocked differently. Am J Community Psychol. 2009;44(3-4):382-93. https://doi.org/10.1007/s10464009-9272-6.

\section{Publisher's Note}

Springer Nature remains neutral with regard to jurisdictional claims in published maps and institutional affiliations.

Ready to submit your research? Choose BMC and benefit from:

- fast, convenient online submission

- thorough peer review by experienced researchers in your field

- rapid publication on acceptance

- support for research data, including large and complex data types

- gold Open Access which fosters wider collaboration and increased citations

- maximum visibility for your research: over $100 \mathrm{M}$ website views per year

At $\mathrm{BMC}$, research is always in progress.

Learn more biomedcentral.com/submissions 